\title{
Lysosomal-Associated Transmembrane Protein 4B
}

National Cancer Institute

\section{Source}

National Cancer Institute. Lysosomal-Associated Transmembrane Protein 4B. NCI

Thesaurus. Code C88217.

Lysosomal-associated transmembrane protein 4B (370 aa, $\sim 41 \mathrm{kDa}$ ) is encoded by the human LAPT M4B gene. This protein may play a role in transport. 